\title{
The Analysis on the Leisure Life of Farmers under the Different Human Capital Levels
}

\author{
Wen Shi \\ College of Economy and Management \\ Shenyang Agricultural University \\ Shenyang, China
}

\author{
Xiaoyan Han \\ College of Economy and Management \\ Shenyang Agricultural University \\ Shenyang, China
}

\begin{abstract}
Leisure has become an important part of modern life. The leisure of the farmers directly influences the quality of farmers' life, and has important significance to the realization of new socialist countryside construction in China. This paper studies the leisure life of farmers under the different human capital levels. The results show that, on one hand, farmers' leisure consumption and leisure time increase with the increase of human capital, and the quality of leisure life will be improved; On the other hand, the overall leisure consumption level of farmers in China is low, and the leisure activities of the household are mainly recreation, and the higher level of leisure activities is scarce.
\end{abstract}

Keywords-human capital; farmers leisure life; leisure consumption; leisure time

\section{PRESENTATION OF QUESTIONS}

Leisure life is an advanced form of human civilization, which is mainly composed of the leisure time and leisure activities, also an important part of the daily life of the farmers. The condition of leisure life not only affects the health of farmers' physical and mental health, but also affects the improvement of the quality of life and the creation of social value. From the material level, the academic community has reached a basic consensus on the positive impact of human capital on the income of farmers. On the immaterial view, the researchers paid little attention to whether the leisure life of farmers will improve with the development of human capital level. Therefore, it is important to understand and master the leisure situation of farmers, especially to understand the leisure condition of farmers under different human capital level, which has a significant practical meaning for our government and organization to develop and guide farmers to leisure, construct healthy, scientific civilized leisure lifestyle, eventually improve the farmers' overall quality, and accelerate the construction of new socialist countryside.

\section{CONCEPT DEFINITIONS}

Schultz, an American economist believes that the human capital of workers presents on the sum of the knowledge, intelligence, skills and health of the workers themselves. In addition, human capital is not innate, it must rely on the investment, and human capital investment channels mainly include: full-time school education, on-the-job training, nutrition and health, migration costs for choosing jobs.
According to the data used in the analysis, the human capital of farmers paper refers to the capital amount focus on farmers which in the form of education, health investment and labor migration. In addition, the perspective of the American economist Torstein Veblen, said that "leisure time refers to the consumption time of no production, that is, the time for free activities and consumer products besides the normal working time." And "leisure means in the consumption time of no production, that is, the process of consumption, social activities, and entertainment in leisure time, which is a process of physical and mental adjustment after labor."

\section{DATA SOURCES}

In this paper, the relevant data of Family Panel Studies China (CFPS) in the Chinese Social Science Research Center of Peking University has been investigated. Take farmer family as the research object, to investigate if the leisure life of farmers has difference and the difference condition under different human capital level. According to this purpose, the farmers' data of Liaoning Province in CFPS2010 are screened, and the sample number of farmers' households is 481, which distribute in 24 villages. In the case of classifying the farmer's human capital, the paper analyzes the situation of 1133 labor which take the family as the unit, while in the analysis of the leisure status of farmers, this paper arrange the CFPS2010 adult questionnaire and get rid of the questionnaire of 16 years old and above who is at school, the number is 1207 after eliminating.

\section{FARMERS' HUMAN CAPITAL CLASSIFICATION}

According to the definition of human capital and the research content of CFPS2010, this paper selects 7 indexes from 3 aspects: education, health status and labor migration to research on the human capital of labor. Among them, the average years of schooling reflect the status of farmers' education level, and the self-reported health score and interviewer evaluation score reflect the health status of the farmers; the number of workers go out for work, go out work time, administrative staff number, if engaged in nonagricultural business reflects the household employment migration status, statistical analysis results are shown in "Table I.". 
TABLE I. HUMAN CAPITAL INDEX OF FARMER HOUSEHOLD

\begin{tabular}{|c|c|c|c|c|}
\hline $\begin{array}{c}\text { Farmer } \\
\text { Fousehold labor } \\
\text { Features }\end{array}$ & $\begin{array}{c}\text { Maximum } \\
\text { value }\end{array}$ & $\begin{array}{c}\text { Minimum } \\
\text { value }\end{array}$ & $\begin{array}{c}\text { Avera } \\
\text { ge }\end{array}$ & $\begin{array}{c}\text { Standard } \\
\text { deviation }\end{array}$ \\
\hline Years of schooling & 16 & 3 & 7.60 & 1.99 \\
\hline $\begin{array}{c}\text { Self-reported } \\
\text { health score }\end{array}$ & 5 & 1 & 4.12 & 0.85 \\
\hline $\begin{array}{c}\text { Interviewer' labor } \\
\text { health evaluation } \\
\text { score }\end{array}$ & 7 & 2 & 5.45 & 1.23 \\
\hline $\begin{array}{c}\text { Number of Family } \\
\text { members working } \\
\text { away from home }\end{array}$ & 4 & 0 & 0.40 & 0.66 \\
\hline $\begin{array}{c}\text { Working time } \\
\text { away from home }\end{array}$ & 12 & 0 & 0.04 & 0.25 \\
\hline $\begin{array}{c}\text { Number of family } \\
\text { member in } \\
\text { administrative } \\
\text { employment }\end{array}$ & 2 & 0 & -136 & 4.13 \\
\hline $\begin{array}{c}\text { Engaged in non- } \\
\text { agricultural } \\
\text { business }\end{array}$ & 1 & 0 & & \\
\hline \begin{tabular}{c} 
Note: On the problem of "if engaged in non-agricultural business ", there are two answers to \\
\hline
\end{tabular} & & 0 & & \\
\hline
\end{tabular}

According to the 7 indicators above, perform cluster analysis of the human capital situation of the 481 households. According to the results of cluster analysis, the farmers are divided into three categories based on the situation of human capital: high human capital, medium human capital, low human capital, and the results are shown in "Table II". From classification results, it is seen that the number of farmers with medium human capital is low; the vast majority of household belongs to the low human capital. These results indicate that the level of human capital of farmers in China is still low, and the sample characteristics of the human capital level are shown in "Table III".

TABLE II. Cluster ANALYsis ON THE Human CAPITAL OF FARMERS

\begin{tabular}{|c|c|c|c|c|}
\hline & $\begin{array}{c}\text { High } \\
\text { human } \\
\text { capital }\end{array}$ & $\begin{array}{c}\text { Medium } \\
\text { human } \\
\text { capital }\end{array}$ & $\begin{array}{c}\text { Low } \\
\text { human } \\
\text { capital }\end{array}$ & Total \\
\hline $\begin{array}{c}\text { The } \\
\text { numbers of } \\
\text { households }\end{array}$ & 148 & 124 & 209 & 481 \\
\hline$\%$ & 30.77 & 25.78 & 43.45 & 100 \\
\hline
\end{tabular}

choose: "yes" or "no". For quantitative analysis, assignment the answer "yes" with 1, assignment answers

"no" with 0.

TABle III. Labors' Feature in DifFerent Human Capital Rural Households

\begin{tabular}{|c|c|c|c|c|c|c|c|}
\hline & \multicolumn{2}{|c|}{ High human capital } & \multicolumn{2}{|c|}{ Medium human capital } & \multicolumn{2}{|c|}{ Low human capital } \\
\hline & & numbers & $\%$ & numbers & $\%$ & numbers & $\%$ \\
\hline \multicolumn{2}{|l|}{ Average age of labor } & 39.30 & - & 39.72 & - & 43.06 & - \\
\hline \multicolumn{2}{|l|}{ Average years of schooling } & 9.42 & - & 7.89 & - & 6.15 & - \\
\hline \multicolumn{2}{|l|}{ The self-reported health score of labor } & 4.33 & - & 4.01 & - & 4.04 & - \\
\hline \multicolumn{2}{|l|}{ Interviewer healthy evaluation score } & 5.60 & {[} & 5.41 & {[} & 5.36 & $\overline{-}$ \\
\hline \multirow[t]{6}{*}{ Number of Family members working away from home } & 0 & 135 & 91.22 & 0 & 0.00 & 188 & 89.95 \\
\hline & 1 & 12 & 8.11 & 102 & 82.26 & 18 & 8.61 \\
\hline & 2 & 1 & 0.67 & 18 & 14.52 & 3 & 1.44 \\
\hline & 3 & 0 & 0.00 & 2 & 1.61 & 0 & 0.00 \\
\hline & 4 & 0 & 0.00 & 2 & 1.61 & 0 & 0.00 \\
\hline & average & 0.09 & - & 1.23 & - & 0.23 & - \\
\hline \multicolumn{2}{|l|}{ Working time away from home } & 3.50 & - & 9.06 & - & 2.93 & - \\
\hline \multirow[t]{3}{*}{ Number of family member in administrative employment } & 0 & 140 & 94.59 & 120 & 96.77 & 203 & 97.13 \\
\hline & 1 & 5 & 3.38 & 4 & 3.23 & 6 & 2.87 \\
\hline & 2 & 3 & 2.03 & 0 & 0.00 & 0 & 0.00 \\
\hline \multirow[t]{2}{*}{ Engaged in non-agricultural business } & yes & 27 & 18.24 & 7 & 5.65 & 14 & 6.70 \\
\hline & no & 121 & 81.76 & 117 & 94.35 & 195 & 93.30 \\
\hline
\end{tabular}


According to the result of the human capital cluster analysis, it can be seen that the longer time educated, the higher human capital the farmer with. In addition, the higher the health level of farmers, the higher level of human capital. According to the situation of the farmers' employment emigration, the medium human capital is higher than that of the high human capital and low human capital in migrant worker number and working time. The migrant proportion is quite low in farmers with high human capital; and medium human capital households all have migrant workers, the difference only in the number of migrant workers; the number of low human capital of migrant workers shows a downward trend, households of no migrant workers experience accounted nearly $90 \%$ of the total number. From the aspect of working time, the same trend with the migrant workers, that is, the average migrant workers time of high human capital and low human capital is shorter, while the average time of medium human capital is longer.

\section{ANALYSIS OF THE LEISURE LIFE OF THE FARMERS UNDER DIFFERENT HUMAN CAPITAL LEVELS}

For individuals, the time is limited every day; we can divide the time based on different circumstances. When CFPS perform investigation, the individual's daily activities divided into seven parts, including: first, personal life activities, refers to meet individual physiological needs and cannot be replaced by the other person to complete the activities, including sleep, dining and other activities; second, personal work, including the first professional work and parttime work two areas; third, learning or training; fourth, entertainment and social interaction, which refers to the recreational activities and social activities which can be dominated totally by oneself ; fifth, traffic activity; sixth, other; seventh, no activity, that means there is no activity. It can be seen from the above classification, personal life time is occupied by all kinds of necessary activities and leisure time together, individual can obtain physical and mental pleasure and self-satisfaction, thereby easing the work pressure and tension, therefore, the individual from the leisure can directly get the utility and restore the work ability, leisure time and quality directly affect the family utility maximization goal of the realization and family welfare.

In general, the study of family leisure life should be carried out in two aspects. On one hand, leisure time is one of the free time that people can dominate freely, which means that the development of individual leisure activities is subject to the amount of free time, the amount of leisure time affects the life quality directly; on the other hand, leisure time does not represent the real leisure, and the structure and quality of leisure activity is also a main content need considered. Therefore, this paper mainly studies the leisure activities of the family from two aspects: consumption and time of leisure activities, leisure activities contents. In addition, when perform analysis of time usage, the time arrangement is divided into two parts, working days and rest days, where the definition of the rest day is not the statutory holidays and workday, the days for rest here means the respondents' own working days and rest days which is not a regular Sunday to Monday.

\section{A. leisure consumption and time}

After the classification of different human capital, the statistic of family culture, entertainment and leisure expenses in first half year founds that, the consumption level of high human capital is the highest, while medium human capital has the lowest level of leisure consumption, the expense of the consumption of high human capital is 7.9 times of the medium human capital, and 4.2 times of the low human capital, and the difference of leisure time consumption of farmers under different human capital is very obvious. "Table IV".

TABLE IV. HOUSEHOLDS CONSUMPTION ON LEISURE

\begin{tabular}{|c|c|c|c|}
\hline & $\begin{array}{c}\text { High } \\
\text { human } \\
\text { capital }\end{array}$ & $\begin{array}{c}\text { Medium } \\
\text { human } \\
\text { capital }\end{array}$ & $\begin{array}{c}\text { Low } \\
\text { human } \\
\text { capital }\end{array}$ \\
\hline $\begin{array}{c}\text { Households consumption } \\
\text { on leisure last year (yuan) }\end{array}$ & 214.83 & 27.24 & 50.96 \\
\hline
\end{tabular}

On the other hand, there are some differences in the individual time allocation (shown in Table $\mathrm{V}$, table VI), according to the statistic of working days and rest days, high human capital farmers' personal life time is the shortest, and personal working hours in the working day is the longest, and the difference of working time between working days and rest days is obvious. In the farmers with medium human capital, low human capital, the time of individual life is longer, while the individual working time is shorter, and the personal working time of farmers with low human capital is the shortest. In the entertainment leisure and social intercourse time, the high human capital has the longest time, while the low human capital has the shortest time.

TABLE V. TIME DistRIBUTION IN WORKING DAYS (UNIT: HOUR)

\begin{tabular}{|l|c|c|c|c|c|c|}
\hline \multirow{2}{*}{$\begin{array}{c}\text { Time } \\
\text { distribution }\end{array}$} & \multicolumn{2}{c|}{$\begin{array}{c}\text { High human } \\
\text { capital }\end{array}$} & \multicolumn{2}{c|}{$\begin{array}{c}\text { Medium } \\
\text { human capital }\end{array}$} & \multicolumn{2}{c|}{$\begin{array}{c}\text { Low human } \\
\text { capital }\end{array}$} \\
\cline { 2 - 7 } & time & $\%$ & time & $\%$ & time & $\%$ \\
\hline $\begin{array}{l}\text { Personal life } \\
\text { activities }\end{array}$ & 12.63 & 52.85 & 12.91 & 54.13 & 13.11 & 55.27 \\
\hline Work & 5.57 & 23.31 & 5.43 & 22.77 & 4.92 & 20.74 \\
\hline $\begin{array}{l}\text { Learning or } \\
\text { training }\end{array}$ & 0.09 & 0.38 & 0 & 0.00 & 0 & 0.00 \\
\hline $\begin{array}{l}\text { Entertainment } \\
\text { and social } \\
\text { activity }\end{array}$ & 3.49 & 14.60 & 3.38 & 14.17 & 3.15 & 13.28 \\
\hline $\begin{array}{l}\text { Traffic } \\
\text { activity }\end{array}$ & 0.28 & 1.17 & 0.28 & 1.17 & 0.32 & 1.35 \\
\hline Other & 0.34 & 1.42 & 0.51 & 2.14 & 0.55 & 2.32 \\
\hline No activity & 1.5 & 6.28 & 1.34 & 5.62 & 1.67 & 7.04 \\
\hline Total & 23.9 & 100.00 & 23.85 & 100.00 & 23.72 & 100.00 \\
\hline
\end{tabular}


TABLE VI. Time Distribution In Rest DAys (Unit: Hour)

\begin{tabular}{|l|c|c|c|c|c|c|}
\hline \multirow{2}{*}{$\begin{array}{c}\text { Time } \\
\text { distribut } \\
\text { ion }\end{array}$} & \multicolumn{2}{|c|}{$\begin{array}{c}\text { High human } \\
\text { capital }\end{array}$} & \multicolumn{2}{c|}{$\begin{array}{c}\text { Medium } \\
\text { human capital }\end{array}$} & \multicolumn{2}{c|}{$\begin{array}{c}\text { Low human } \\
\text { capital }\end{array}$} \\
\cline { 2 - 7 } & time & \% & time & $\%$ & time & $\%$ \\
\hline $\begin{array}{l}\text { Personal } \\
\text { life } \\
\text { activities }\end{array}$ & 13.2 & 55.70 & 13.22 & 55.62 & 13.29 & 56.34 \\
\hline $\begin{array}{l}\text { Work } \\
\text { Learning } \\
\text { or } \\
\text { training }\end{array}$ & 3.78 & 15.95 & 4 & 16.83 & 3.86 & 16.36 \\
\hline $\begin{array}{l}\text { Entertain } \\
\text { ment and } \\
\text { social } \\
\text { activity }\end{array}$ & 4.03 & 17.00 & 3.87 & 16.28 & 3.42 & 14.50 \\
\hline $\begin{array}{l}\text { Traffic } \\
\text { activity }\end{array}$ & 0.25 & 1.05 & 0.29 & 1.22 & 0.29 & 1.23 \\
\hline $\begin{array}{l}\text { Other } \\
\text { Total }\end{array}$ & 23.7 & 100.00 & 23.77 & 100.00 & 23.59 & 100.0 \\
\hline $\begin{array}{l}\text { No } \\
\text { activity }\end{array}$ & 2.05 & 8.65 & 1.77 & 7.45 & 2.09 & 8.86 \\
\hline & 1.52 & 0.62 & 2.61 & 0.62 & 2.63 \\
\hline
\end{tabular}

From the above analysis, it can be seen that there are some differences between the different human capitals of rural farmers, whether from the perspective of family leisure consumption or leisure time, the leisure life of farmers with high human capital is higher than that of the farmers with medium human capital.

\section{B. leisure activities}

According to the time distribution of entertainment leisure and social intercourse, the leisure activities of the farmers are relatively abundant at present (shown in Table VII). According to the statistic of working day and rest day two kinds, at present, the most extensive entertainment and leisure activities in rural areas is transitionally watching television, CD-ROM, listen to radio or listen to music. Whether it is a farmer with high human capital or a low human capital, their daily watching TV, listening to the radio is about 2 hours. On the working day, the time of this activity of the farmers with low human capital is the longest, and the time of the farmers with high human capital is the shortest. When the day of rest, the farmer with high human capital is the longest, the farmer with medium human capital is the shortest. In addition, the more popular recreational activities is social interaction, take activities for hobbies, play games and perform entertainment, but the time of these activities has great difference with time spent watching TV, listening to the radio.
TABLE VII. Time Distribution of Leisure Activities (Unit: Hour)

\begin{tabular}{|c|c|c|c|c|c|c|}
\hline \multirow[t]{2}{*}{$\begin{array}{c}\text { Leisure } \\
\text { activities }\end{array}$} & \multicolumn{2}{|c|}{$\begin{array}{l}\text { High human } \\
\text { capital }\end{array}$} & \multicolumn{2}{|c|}{$\begin{array}{c}\text { Medium } \\
\text { human capital }\end{array}$} & \multicolumn{2}{|c|}{$\begin{array}{l}\text { Low human } \\
\text { capital }\end{array}$} \\
\hline & $\begin{array}{c}\text { Working } \\
\text { days }\end{array}$ & $\begin{array}{l}\text { Rest } \\
\text { days }\end{array}$ & $\begin{array}{c}\text { Working } \\
\text { days }\end{array}$ & $\begin{array}{l}\text { Rest } \\
\text { days }\end{array}$ & $\begin{array}{c}\text { Working } \\
\text { days }\end{array}$ & $\begin{array}{l}\text { Rest } \\
\text { days }\end{array}$ \\
\hline $\begin{array}{l}\text { Read the } \\
\text { traditional } \\
\text { media }\end{array}$ & 0.18 & 0.19 & 0.13 & 0.15 & 0.07 & 0.08 \\
\hline $\begin{array}{l}\text { Watch TV, } \\
\text { CD-ROM/ } \\
\text { listen to radio } \\
\text { /listen to } \\
\text { music }\end{array}$ & 1.93 & 2.14 & 1.86 & 2.04 & 1.95 & 2.11 \\
\hline $\begin{array}{l}\text { The use of } \\
\text { internet } \\
\text { entertainment }\end{array}$ & 0.26 & 0.36 & 0.17 & 0.20 & 0.07 & 0.09 \\
\hline $\begin{array}{l}\text { Physical } \\
\text { training and } \\
\text { fitness } \\
\text { activities }\end{array}$ & 0.16 & 0.18 & 0.15 & 0.14 & 0.13 & 0.13 \\
\hline $\begin{array}{l}\text { Hobbies, fun } \\
\text { activities }\end{array}$ & 0.35 & 0.43 & 0.36 & 0.57 & 0.34 & 0.40 \\
\hline $\begin{array}{l}\text { Social } \\
\text { interaction }\end{array}$ & 0.57 & 0.70 & 0.65 & 0.71 & 0.56 & 0.60 \\
\hline $\begin{array}{l}\text { Community } \\
\text { service and } \\
\text { public } \\
\text { interests } \\
\text { activities }\end{array}$ & 0.01 & 0.01 & 0.02 & 0.02 & 0.00 & 0.00 \\
\hline $\begin{array}{l}\text { Religious } \\
\text { activities }\end{array}$ & 0.02 & 0.02 & 0.03 & 0.03 & 0.02 & 0.02 \\
\hline Total & 3.48 & 4.03 & 3.37 & 3.86 & 3.14 & 3.43 \\
\hline
\end{tabular}

In order to better tell the difference of the leisure life of the farmers with different human capital level, entertainment leisure and social intercourse activities in table 7 are classified into four categories, that is, entertainment type, development type, social intercourse type and belief service type. The entertainment type means the leisure activities not need professional leisure skills, simply for purpose of pastime such as watching TV, listening to radio, the use of internet entertainment, hobbies, games and pastime activities. The development type refers to the leisure activity for the purpose of improve oneself, including reading the traditional media, physical training and fitness activities, through this way can achieve the growth of knowledge, cultivate sentiment. Social interaction type is mainly reflected in the social identity, information transmission, solving contradiction and other functions, for example, go out for dining belongs to this type. Belief service type mainly includes community service and public welfare activities and religious activities, which focus on the pleasure and satisfaction of spirit. In accordance with the above criteria for classification, different human capital of farmers' leisure activity time classified and arranged (shown in Table VIII, Table IX). According to the result of the arrangement, it can 
be seen that the farmers with low human capital has the shortest time of leisure activities no matter what type of leisure activity, while the farmers with high human capital has longer time in the entertainment type and development type than the farmers with medium human capital, but shorter in the time of the social intercourse and belief service type than the farmers with medium human capital.

TABLE VIII. TIME CLASSIFICATION OF LEISURE ACTIVITIES IN WORKING DAYS (UNIT: HOUR)

\begin{tabular}{|c|c|c|c|c|c|c|}
\hline \multirow{2}{*}{$\begin{array}{c}\text { Classification of } \\
\text { leisure activities }\end{array}$} & \multicolumn{2}{|c|}{$\begin{array}{c}\text { High human } \\
\text { capital }\end{array}$} & \multicolumn{2}{c|}{$\begin{array}{c}\text { Medium } \\
\text { human capital }\end{array}$} & \multicolumn{2}{c|}{$\begin{array}{c}\text { Low human } \\
\text { capital }\end{array}$} \\
\cline { 2 - 7 } & Time & $\%$ & Time & $\%$ & Time & $\%$ \\
\hline $\begin{array}{c}\text { Entertainment } \\
\text { type }\end{array}$ & 2.54 & 72.99 & 2.39 & 70.92 & 2.36 & 75.16 \\
\hline Development type & 0.34 & 9.77 & 0.28 & 8.31 & 0.2 & 6.37 \\
\hline $\begin{array}{c}\text { Social intercourse } \\
\text { type }\end{array}$ & 0.57 & 16.38 & 0.65 & 19.29 & 0.56 & 17.83 \\
\hline $\begin{array}{c}\text { Religious belief } \\
\text { service type }\end{array}$ & 0.03 & 0.86 & 0.05 & 1.48 & 0.02 & 0.64 \\
\hline Total & $\mathbf{3 . 4 8}$ & $\mathbf{1 0 0 . 0 0}$ & $\mathbf{3 . 3 7}$ & $\mathbf{1 0 0 . 0 0}$ & $\mathbf{3 . 1 4}$ & $\mathbf{1 0 0 . 0 0}$ \\
\hline
\end{tabular}

TABLE IX. TIME ClassifiCATION OF LEISURE ACTIVITIES IN REST DAYS (UNIT: HOUR)

\begin{tabular}{|c|c|c|c|c|c|c|}
\hline \multirow{2}{*}{$\begin{array}{c}\text { Classification of } \\
\text { leisure activities }\end{array}$} & \multicolumn{2}{|c|}{$\begin{array}{c}\text { High human } \\
\text { capital }\end{array}$} & \multicolumn{2}{c|}{$\begin{array}{c}\text { Medium } \\
\text { human capital }\end{array}$} & \multicolumn{2}{c|}{$\begin{array}{c}\text { Low human } \\
\text { capital }\end{array}$} \\
\cline { 2 - 7 } & Time & $\%$ & Time & \% & Time & $\%$ \\
\hline $\begin{array}{c}\text { Entertainment } \\
\text { type }\end{array}$ & 2.93 & 72.70 & 2.81 & 72.80 & 2.6 & 75.80 \\
\hline $\begin{array}{c}\text { Development type } \\
\text { Social intercourse } \\
\text { type }\end{array}$ & 0.37 & 9.18 & 0.29 & 7.51 & 0.21 & 6.12 \\
\hline $\begin{array}{c}\text { Religious belief } \\
\text { service type }\end{array}$ & 0.03 & 0.74 & 0.05 & 1.30 & 0.02 & 0.58 \\
\hline Total & $\mathbf{4 . 0 3}$ & $\mathbf{1 0 0 . 0 0}$ & $\mathbf{3 . 8 6}$ & $\mathbf{1 0 0 . 0 0}$ & $\mathbf{3 . 4 3}$ & $\mathbf{1 0 0 . 0 0}$ \\
\hline \multicolumn{2}{|c|}{} & & 0.71 & 18.39 & 0.6 & 17.49 \\
\hline
\end{tabular}

\section{CONCLUSIONS AND RECOMMENDATIONS}

From the analysis above, it can be seen that there are some differences of the leisure life of farmers with different human capital. Which performs in: whether it is from the family leisure consumption, leisure time, the level of leisure life of farmers with high human capitals higher than the quality of farmers with medium of human capital or low human capital. In addition, from the quality of leisure life, the types of leisure activities in rural areas is abundant, but the overall level is not high, no matter what kind of human capital, the main leisure activities is entertainment leisure activities, followed by the social intercourse type activities, while the development of improved, belief service activities carried out less. This shows that in rural areas, the traditional leisure activities still occupy a dominant position. Comparatively, the quality of leisure activity of farmers with high human capital is higher than that of farmers with medium human capital, and the lowest quality is of farmers with low human capital. And the main purpose of the leisure activities of the farmers is just the relaxing of the spirit, the pursuit of entertainment, and has no ability to learn though leisure activities in order to cultivate the sentiment and improve the quality.

Accordingly, this paper puts forward the following policy recommendations: first, the government should increase investment, and build essential places for leisure activities. With the support and set of public products, the quality of leisure life of residents will also be improved. The entertainment and leisure places provided by the government offers possibility to read, communicate and other activities which provide a stage for the promotion of the spirit life. Second, organizations at all levels should actively guide farmers to participate in healthy, spiritual and cultural activities. The leisure activities in rural areas not only stay in the entertainment levels, also should be supplemented with the development type of leisure activities, change from the traditionally watching TV, listening to radio and other leisure activities to the participate type, characteristics leisure activities, through this way, enhance the farmers' originality and development potential.

\section{REFERENCES}

[1] Kong Wenyu., Analysis on the behavior of farmers' leisure life in China, Journal of Shanxi Agricultural University (Social Science Edition), issue 3, pp. 299-301, 2010.

[2] Xu Xiaoyun, Characteristics and optimization of the leisure life of the farmers -- a case study of W village in the Loess Plateau of Northwest China, Journal of Hunan Agricultural University (Social Science Edition), issue 3,pp. 36-41, 2010.

[3] Liu Hairong, Predicament and outlet of Chinese farmers' leisure life, Economic Research Guide, issue 34,pp. 54-55+71, 2011.

[4] Zhang Hongxia, Peasants' leisure life in rural cultural changes, Journal of Shandong Agricultural Engineering College, issue 4, pp. 11-12,2010.

[5] Xie Yun, Investigation and analysis leisure time of farmers in major grain producing areas, Journal of Yangtze University (Nature Science Edition) volume of Agriculture, issue 3, pp. 103-106, 2009. 